\title{
Confesores y casaderas: la nupcialidad subyacente en la ética matrimonial de la Iglesia novohispana
}

\author{
Juan Javier Pescador
}

Sin pretender establecer una relación directa de causalidad, el presente trabajo estudia las implicaciones demográficas que, a nivel nupcialidad, fecundidad y anticoncepción tenía contenidas la ética matrimonial de la iglesia en Nueva España. Se estudian las recomendaciones y mandatos eclesiásticos sobre lo que hoy se conoce como variables demográficas : la edad a la primera unión, la exogamia y endogamia étnicas, el mestizaje, la viudez, el número de hijos y la anticoncepción.

El estudio se lleva a cabo a través del análisis de documentos de la iglesia en la Nueva España, tales como los concilios provinciales y algunos confesionarios -especialmente el de fray Alonso de Molina.

\section{Introducción}

La comprensión de los fenómenos demográficos implica el conocimiento de los patrones de conducta de las poblaciones estudiadas.

No basta con establecer de una manera pulcra y ordenada las relaciones de magnitud y rango que asumen los valores de las variables que trabajamos, sino que es también necesario investigar aquellas instituciones, prácticas y actitudes que operan sobre nuestras poblaciones, así como el carácter de las relaciones con que aquéllas se vinculan a la dinámica demográfica, ya condicionándola, ya determinándola.

En lo que se refiere particularmente a los estudios de nupcialidad para la Nueva España, existen trabajos que se han ocupado de encontrar las relaciones cuantitativas y los valores numéricos que asumen los distintos indicadores de la nupcialidad novohispana, llegando a delinear, a grandes rasgos, los patrones de enlace vigentes en la época; esto sólo para ciertas parroquias, las más de ellas rurales y en ciertos periodos.

Valiosas aportaciones han significado tales trabajos, ${ }^{1}$ basándose en la explotación sistemática de los registros parroquiales con las técnicas y métodos modernos de la demografía histórica.

Se sabe que los matrimonios en sociedades no industriales son eventos de una gran significancia, pues constituyen el mecanismo más eficaz de que dispone la población para autorregularse, dado el supuesto de que la fecundidad no dirigida impera en dichas formaciones sociales.

Es sólo a través de los cambios coyunturales y en el tiempo corto que se da en los patrones de nupcialidad, la población logra compensar -en

${ }^{1}$ Para el balance de los trabajos sobre nupcialidad novohispana y sobre la demografia histórica novohispana en general, véase: Cecilia Rabell, "La población novohispana a la luz de los registros parroquiales", tesis de maestria en demografía cendu/Colmex, México, 1984. 
lo posible- los devastadores efectos de las crisis demográficas que, periódicamente, diezmaban a los habitantes de las parroquias novohispanas. ${ }^{2}$

La población sólo puede reajustarse a través de los cambios en las variables clásicas de nupcialidad; es decir, en las alteraciones de la edad a la primera unión, en la frecuencia del celibato definitivo, en la duración de la viudez, en la proporción de segundas y ulteriores nupcias, en las pautas de endogamia y exogamia étnicas, en los cambios de las pautas de ilegitimidad, etcétera.

Siguiendo el balance hecho por Rabell, se sabe que no hay un solo patrón de enlace para todo el reino, ni aun para los grupos étnicos vecinos de una misma comunidad.

La edad media para llegar al matrimonio, por ilustrar lo antes dicho, es bastante menor en las mujeres indígenas que en las castas; en las castas que en las españolas, y en las mujeres de Nueva España que en las de la Europa Occidental estudiada.

La frecuencia de segundas y ulteriores nupcias es mucho más intensa en las parroquias mexicanas que se han trabajado, que en las francesas contemporáneas.

El celibato definitivo prácticamente no existe entre las mujeres indias, lo que no ocurre con españolas y castas; las proporciones de ilegitimidad también son más altas aquí que en Europa, así como el promedio de vida reproductiva marital.

Por otra parte, se sabe que la nupcialidad es igualmente sensible a los procesos en que se dan los cambios y las continuidades culturales, es decir, a las actitudes, concepciones y valores que dichas poblaciones tenían frente al matrimonio, la muerte, la salvación del alma, la transmisión de la herencia, la virginidad, la procreación, el pecado o la honra, por ejemplo.

El presente trabajo tiene como objetivo el formular la ética matrimonial católica vigente en el México colonial como un problema demográfico. Es decir, se pretende analizar cuáles de las normas eclesiásticas matrimoniales son traducibles en términos de propuestas demográficas a la población sobre sus pautas reproductivas.

Es obvio que no se piensa que el discurso eclesiástico es similar al demográfico, pero se parte de que en las propuestas de aquél para normar la conducta de la feligresía subyacen también - hayan sido o no producto de la voluntad de teólogos, moralistas y confesores- lineamientos morales que tienden a propiciar que los patrones de nupcialidad se den, junto con las pautas de fecundidad, de una manera determinada.

No planteamos ni buscamos demostrar que en la regulación eclesiástica debemos hallar los determinantes directos de las pautas nupciales, ni siquiera que su influencia haya sido la definitiva. La pretensión gira, más

2 Ibidem; véanse los subcapitulos dedicados a los matrimonios. 
bien, en torno a incorporar la ética eclesiástica sobre el matrimonio como problema demográfico.

La Iglesia novohispana mantiene principios, cuyo carácter puede ir desde la recomendación amable hasta la obligación insoslayable, que, indudablemente, conciernen a las pautas demográficas de nupcialidad y fecundidad. Nuestro propósito es evaluar tales principios en términos de aclarar a qué tipo de propuesta demográfica conducen, o bien, por decirlo desde el extremo opuesto, aclarar qué significa acatar la ética matrimonial cristiana, en términos de pautas de enlace y reproducción.

Los documentos en los que se basa este ensayo corresponden en su mayoría a la iglesia novohispana, mereciendo especial atención los manuales para confesar o confesionarios - sobre todo el de fray Alonso de Molina-y las resoluciones de los tres primeros concilios provinciales llevados a cabo en la época virreinal.

De los confesionarios cabe apuntar que son una fuente inapreciable para los estudiosos de la historia de la familia y la demografía histórica, pues en ellos aparecen capítulos enteros dedicados a las relaciones domésticas y al trato que se debían tener los miembros de una familia de acuerdo con la posición que en ella ocupaban. Igualmente se encuentra en estos manuales información sobre los probables tropiezos y resistencias que la ética familiar cristiana podía encontrar en sus feligreses, así como menciones a las desviaciones y desobediencias más frecuentes entre los parroquianos. El confesionario de Molina -y ésta es una de las razones por las que es el más utilizado en este trabajo- llega incluso a contemplar un apartado especial dedicado a los futuros esposos, donde se les indica, en forma detallada, el tipo de relación marital y conyugal que deben llevar.

En cuanto a los estudios modernos sobre la historia de la norma eclesiástica y su relación con la familia, la sexualidad, la anticoncepción y el matrimonio, cabe destacar el trabajo pionero de Noonan (1965), los trabajos de Flandrin $(1969,1972$ y 1979) y los de la historia de la familia en Francia en general.

En la historia de la familia en Nueva España destacan los estudios del seminario de historia de las mentalidades del INAH y el trabajo de Viqueira (1984) sobre matrimonio y sexualidad en los confesionarios en lenguas indígenas.

\section{El matrimonio eclesiástico y sus propósitos. Siglos XVI-XVIII}

"Pues es cosa Santa el matrimonio y santamente debe tratarse" Concilio de Trento xxrv, sesión 11 de noviembre de 1563.

El ideal de vida cristiano era, en sus términos más generales, la lucha permanente por la salvación del alma. Esto suponía una constante oposición a todos los valores y las representaciones mundanas. 
Esta actitud tuvo una gran influencia en la valoración que el matrimonio significó para la iglesia católica en general, y novohispana en particular. En la contienda por la salvación eterna del alma, los adversarios más poderosos que debía enfrentar todo cristiano eran el mundo, el cuerpo y el diablo.

Noonan ha subrayado ${ }^{3}$ que todo pecado mortal se podía definir como la preferencia de un fin temporal a la unión eterna con Dios. Esta gama de fines temporales era proporcionada por los enemigos del ánima ya señalados. La sexualidad, que sometía el alma al cuerpo y que mostraba los placeres mundanos, era una tentación particularmente detestable para la Iglesia, ya que juntaba en un solo acto cuerpo y mundo; por ello siempre encontró en ésta una actitud intolerante y abiertamente hostil. ${ }^{4}$

Un hombre entregado a la lujuria quedaba'atado al mundo y a su propio cuerpo a través de los deleites que experimentaba. Esta pasión ardorosa no era para la Iglesia sino el preámbulo de las llamas del infierno en las que se consumiría para siempre el pecador. Es decir, los tormentos que constituirían el castigo eterno de quien se había abandonado a las tentaciones del cuerpo eran tan sólo una reproducción amplificada del placer mundano, pero mostrado en toda su vileza.

En el confesionario de fray Juan de la Anunciación (1575) aparecía un ejemplo detallado de este tormento: ${ }^{5}$

\begin{abstract}
...Y luego comenzarán de los lujuriosos, a quien darán una mujer de fuego y harán que la abracen [aunque les pese] por el vano y sucio deleite que tuvieron con las mujeres, diciéndoles:

Véis aqui, desventurados, vuestro vano y breve deleite, y las cosas de él que tuvisteis en los tiempos atrás, en que vivíades en el mundo.

Por lo cual, el que fue desvergonzado lujurioso dará, sin provecho, grandes voces, porque ambos a dos, perpétuamente, estarán ardiendo y desnaciéndose, con rabia y a bocados. Y lo mismo sucederá con la mujer lujuriosa...
\end{abstract}

El cuerpo humano, obra de Dios pero también morada del diablo, constituía, con sus cinco sentidos, la vía más fácil y rápida al infierno. Por ello, la Iglesia emprendió una lucha sin cuartel en contra de la sensualidad en general, y de la sexualidad en particular. Los sentidos eran la puerta de entrada de la tentación. Fray Alonso de Molina incluía en su "Confesio-

\footnotetext{
${ }^{3}$ John Noonan, Contraception. A History of Its Treatment by the Catholic Theologians and Canonists, Cambridge, Mass., 1965 Harvard University Press, pp. 320 y ss., y Jean-Lou is Flandrin, "Contraception, mariage et relations amoreuses dans l'Occident chrétien", en Annales E.S.C. núm. 6, París, 1969, pp. 1371-1390 (p. 1380).

${ }^{4}$ Juan Pedro Viqueira, "Matrimonio y sexualidad en los confesionarios en lenguas indigenas", en Revista Cuicuilco, núm. 12, México, 1984, pp. 27-37 (pp. 29 y ss.).

${ }^{5}$ Ibidem, p. 28.
} 
nario Mayor" [1569] nueve preguntas que debía hacer el confesor al penitente, sobre los sentidos, entre las que destacan: ${ }^{6}$

¿Miras a tí muchas veces, y deseas que otros te miren, y deseas ser codiciado $\mathrm{y}$ visto, por tu soberbia y por querer ser estimado? [...]

¿Tuviste por muy suave y gustoso el sabor, la suavidad; olor y dulzura del vino de Castilla, o del de esta tierra, y de las otras cosas comescibles y de beber, deleitándote demasiadamente, con la sensualidad y apetito de la gula: y corporal deleite y gusto de los manjares? [...]

¿Aficionaste mucho [por ventura] y amaste las cosas muy blandas, muelles y sensuales: y vestiste siempre, y usas de vestiduras blandas y de camas mullidas y de otras ropas curiosas, menospreciando las vestiduras ásperas y gruesas: que provocan a penitencia y dan aflicción y trabajo, con que se alcanza la salvación.?

El cuerpo, como materia corrupta y finita, debía ser castigado, flagelado y sometido a las necesidades del alma. Toda esta violencia en contra suya quedaba justificada en tanto que éste no pertenecía al alma ni a las cosas celestiales, sino al mundo y las cosas terrenales. De ahí la permanente analogía pronunciada en los rituales entre la carne humana y el polvo de la tierra; entre el tiempo del cuerpo y el de las frutas maduras de la tierra, donde ambos terminarán agusanados y podridos; entre el placer pasajero corporal y el placer - pasajero también-que los frutos de la tierra proporcionan.

Molina, al escribir sobre cómo se debía redactar un testamento, ejemplificaba el desprecio cristiano por el cuerpo: ${ }^{7}$

Después que mi ánima se haya apartado del cuerpo, el dicho cuerpo dejo y encomiendo a la tierra, donde salió, porque es tierra y Iodo, y quiero que sea envuelto en una sola sábana, pa enterrarle...

El verdadero cristiano tenía que elegir las cosas del cielo sobre las de la tierra, pues ante aquéllas, que eran eternas y verdaderas, éstas no eran sino perecederas y caducas, breves y vanas. La salvación consistía en elegir correctamente, en saber preferir el amor a Dios por encima de cualquier apego a las cosas del mundo. Así lo escribía Molina: ${ }^{8}$

Porque has de saber que el que se aficiona y ama mucho las cosas terrenales, luego se hace enemigo de nuestro señor Dios. Mas el verdadero cristiano no se deleita en las cosas mundanas, que engañan, mas deléitase en las cosas del

${ }^{6}$ Fray Alonso de Molina, Confesionario Mayor en la lengua mexicana y castellana (1565 primera edición), México, 1983. Suplemento al Boletín del Instituto de Investigaciones Bibliográficas/UNAM, pp. 101-103.

7 Ibidem, p. 61 (el subrayado es mío).

8 Ibidem, p. 102. 
cielo, que después se han de alcanzar. E por esto conviene tener templanza acerca de las cosas terrenales, breves y caducas: y que han de pasar de priesa, para no perder por ellas la gloria del cielo, la cual no tendrá fin, ni se acabará [...] y tú, cristiano, conviene que sepas que no es posible, ni es cosa que puede ser, durar mucho tiempo dentro de tí estos dos amores: conviene a saber, el amor de Dios, y el amor de las cosas...

Bajo estas premisas, el matrimonio, como contrato civil, poco o nada tenía que ver con los ideales de salvación y vida eterna cristian os. Finalmente, el casarse por perpetuar el linaje de una familia, por establecer una alianza entre parentelas distintas, por incrementar la fortuna o el poder o los negocios de una casa señorial o bien por amor y deseo hacia una persona, no era sino mostrar un excesivo apego a las cosas del mundo y del cuerpo. Por eso, para la iglesia, el único estado acorde con la fe era el celibato; la virginidad. Sólo ella se erigía como una auténtica renuncia a la existencia terrenal. Sólo ella podía permitir la dedicación completa e íntegra a la búsqueda de la salvación espiritual.

La iglesia recomendaba, en sus inicios, el celibato, no el matrimonio, el cual, con los lazos conyugales, familiares y políticos, que indudablemente entrañaba, fijaba al cristiano al mundo; lo amarraba a su vicioso paladar, convirtiéndolo en un pecador con pocas esperanzas de evitar la perdición.

Hay que recordar que, de hecho, el Concilio de Trento sólo se ocupó del matrimonio y sus reformas hasta la penúltima sesión, en 1563, donde quedó establecida, además, la irrefutable superioridad del celibato y la virginidad sobre el estado matrimonial: ${ }^{9}$

\section{CANON X}

Si alguno dijere que el estado de Matrimonio es preferible al de virginidad o celibato, y que no es mejor ni más felíz permanecer en estado de virginidad o celibato, que el casarse, sea excomulgado...

Sin embargo, la iglesia tuvo que aceptar (sobre todo a partir de las sesiones tridentinas) el hecho de que la mayoría de los cristianos eran sencillamente incapaces de resistir las mortificaciones y limitaciones que la virginidad les imponía; tuvo que aceptar también que, ante la falta de fortaleza y templanza del cristiano común para sortear las austeridades que implicaba el celibato, la rigidez de la norma -antes que ser acatada al pie de la letra por los fieles- los precipitaba en todo tipo de excesos y libertinajes.

Máxime que el matrimonio eclesiástico no era -en la Nueva España- la única vía social de formar una pareja y una familia, sino que ade-

${ }^{9}$ Anastasio Machuca Diez, Los Sacrosantos concilios de Trento y Vaticano, en latín y castellono, Madrid, 1903, p. 305. 
más coexistían con él muy poderosas instituciones, como el amancebamiento y el concubinato, cuya fuerte presencia está fuera de discusión -sobre todo en el primer caso-. De ahí que el matrimonio fuera aceptado por la iglesia como un mol menor, es decir, algo recomendable sólo cuando hombre y mujer se mostraban incapaces de vencer las tentaciones carnales. De esta manera, si de no hacerlo se podían caer en mucho mayores males, era lícito y bien visto por la Iglesia el contraer nupcias.

Así, fue para mitigar las flaquezas de la carne, sin precipitarse en los excesos, como comenzó a ser visto el matrimonio por la iglesia católica. Los términos, posibilidades y limitaciones de la aceptación parcial de la sexualidad dentro del matrimonio los analizaremos en los siguientes capítulos.

Esto no significaba, desde luego, que el matrimonio eclesiástico liberara a la sexualidad de toda impureza e inmundicia que le eran intrínsecas; es decir, el matrimonio no sería un espacio para que los esposos cristianos desplegaran sus apetitos carnales, sino para que encontraran una forma más eficaz de reprimirlos.

Para explicar la aceptación parcial de la sexualidad en el matrimonio, como una forma de seguir controlándola, la Iglesia tuvo que construir un sentido en esta relación [matrimonio-contacto sexual]; es decir, tuvo que asignar a la cópula matrimonial fines y propósitos que fueran más allá del mero acto sexual, de tal manera que éste quedara justificado por un origen distinto de él [el matrimonio] y por un fin igualmente distinto [la procreación]. Así, pronto se llegó a pensar, dentro de la iglesia, que el matrimonio, pese a ser un mal menor, ofrecía menos posibilidades de perdición que las que, sin duda, se cernían sobre quienes practicaban el celibato no acompañado de voto de castidad.

Mucho más expuesta al adulterio, el incesto, la sodomía, el bestialismo o la molicie estaba la persona que - no siendo del brazo eclesiásticovivía en soltería, que aquella casada como "Dios manda", la cual tenía una manera de canalizar sus impulsos y de reparar con penitencias las faltas cometidas dentro del matrimonio; todo lo cual llevó a los teólogos y canonistas a preocuparse más por regular las relaciones internas del matrimonio, y a sospechar abiertamente de hombres y mujeres solteros que no acompañaban su virginidad con voto de castidad.

La Iglesia terminó pugnando porque estas personas contrajeran nupcias lo antes posible, en vista de que en cualquier momento podrían incurrir en pecados sumamente graves, como el adulterio o el incesto, o bien en costumbres ocultas, a no dudar pecaminosas, como la molicie o el bestialismo. El matrimonio pronto fue ya no sólo un mal menor, sino también un mal necesario alentado por la propia iglesia católica. De esta forma la vigilancia y el interés eclesiástico en el matrimonio fueron creciendo a lo largo del periodo colonial.

En 1555, el I Concilio Provincial Mexicano le dedicó seis capítulos 
- de un total de 93- y lo definió como una institución divina y natural. ${ }^{10}$ El Concilio de Trento, por su parte, lo definía como un vínculo perpetuo e indisoluble, además de amenazar con la pena de excomunión a quien dijere o hiciere algo que contraviniera estos principios. ${ }^{11} \mathrm{El}$ III Concilio Provincial Mexicano (1589) le asignaba como fines el: "...pasar la vida conyugal con toda piedad y tranquilidad, como para educar a la prole y dirigirla al reino de nuestra patria..."12

Señalaba, además, que no era sino Dios quien unía a la pareja con el vínculo. ${ }^{13}$ De esta manera el matrimonio eclesiástico quedó configurado como sacramento -en términos teológicos- cuyo carácter consistiría en ser una alianza monogámica, indisoluble, única y perpetua. ${ }^{14}$ Indisoluble porque no se podía desintegrar el vínculo sino con la muerte de uno de los cónyuges. El carácter monogámico tendría un matiz a señalar, o sea el hecho de que, al fallecer uno de los esposos, el otro podía contraer nuevas nupcias, practicándose así la poliandria y poligamia sucesivas, con lo que no sería la unión monogámica estrictamente la única permitida, aunque sí la generalizada.

Cabe la aclaración de que el carácter perpetuo del vínculo sólo se refiere al lapso de vida de los casados. Es decir, como el alma no tiene sexo ni estado matrimonial, las personas sólo podían estar casadas "en vida". Las actas de defunciones parroquiales así lo indican, pues junto al nombre de la persona fallecida, viene - por lo general- la frase común "casada/o que fue, en vida, con fulano/a de tal", con lo cual se subrayaba la concepción religiosa del matrimonio como mal necesario, pues, a fin de cuentas, era un vínculo que no sobrevivía ni se remontaba más allá de la muerte del cuerpo.

El propósito de los teólogos al respaldar un contrato civil, como el matrimonio, era el de limitar la vida sexual, y sus tentaciones en general, a un nivel controlable, que pudiera seguir garantizando la salvación de las almas. Sin duda, esto era más fácil de llevar a cabo a través de una alianza monogámica e indisoluble que impusiera el tener solamente una pareja a lo largo de la existencia. Este tipo de enlace, pensaban los teólogos y confesores, acabaría por apaciguar los deseos de ambos cónyuges, en tanto que la variedad de posibles encuentros sexuales no haría sino avi-

${ }^{10}$ Concilios Provinciales primero y segundo, celebrados en la Muy Noble y Muy Leal Ciudad de México..., México, 1891, Imprentadel Agua,2 vols., edición facsimilar de la de José de Hogal (publicados por el arzobispo Lorenzana), México, 1769, p. 104.

11 Op. cit., pp. 301 y 304.

12 El III Concilio Provincial Mexicano, publicado por Mariano Galván Rivera, México, 1859, Eugenio Maillefort y Cía. ed,, p. 343.

13 Ibidem, p. 350.

${ }^{14}$ Dolores Encino Rojas, Un caso de perversión de las normas matrimoniales. El bigamo José de la Peña, en Sergio Ortega (ed.) De la santidad a la perversión..., México, 1985, Enlace/Grijalbo, p.180. 
var las llamas de la lujuria. La oposición terminante al divorcio, por parte de la iglesia, se finca en esta concepción. ${ }^{15}$ Incluso la separación -temporal o definitiva- de los cónyuges siempre fue duramente criticada.

De esta manera, la iglesia fijó claramente los propósitos y las limitaciones del matrimonio. Fray Alonso de Molina incluyó en su confesionario el cómo debía celebrarse la ceremonia. Los propósitos que Molina pone en boca del sacerdote que en ella participa son interesantes e ilustrativos: ${ }^{16}$

El sacerdote: (a los novios): ...es [obligación] que enderezéis la intención de vuestro casamiento a Nuestro Señor, casándoos por su amor, y no por la sucia delectación de la lujuria, ni por las riquezas y bienes mundanales, o por alguna altivez de soberbia o vanagloria [...] Para agradecerle [a Dios] y complacerle con vuestro matrimonio: y para haber hijos, los cuales, en este mundo y en el cielo, alaben y glorifiquen para siempre a su Majestad. Por tanto, conviene mucho que tengáis gran cuidado de vuestros hijos (cuando el único y sólo Dios os los diere) de manera que los criéis y doctrinéis en las cosas de Dios [...] Pues véis aquí, como principalmente por la procreación de ios hijos se casan los fieles: y no por la deleitación carnal, la cual es de ningún provecho. También os habéis de casar por la continencia, para que de aquí en adelante, no os amancebéis, ni cometáis adulterios teniendo parte con la que es casada [...] También os habéis de casar por deseo de adquirir la gracia de nuestro señor [...] la cual da gran contentamiento, y hace ricas, bienaventuradas y llenas de toda prosperidad nuestras ánimas, porque las hace hijas suyas nuestro señor Dios. Asimismo os habéis de casar para ayudaros espiritualmente [...] para os ayudar en vuestras necesidades corporales [...] Pues ahora hijos míos, yo os digo en verdad, que si hiciéredes todas estas cosas, si debidamente recibiéredes el sacramento, seréis, sin duda alguna, salvos, cuando viniere el fin de vuestra vida...

Así la salvación, la procreación, la continencia, la gracia y la ayuda espiritual y corporal entre los cónyuges eran los propósitos cristianos del matrimonio, aunque hay que señalar que no todos eran de igual importancia y jerarquía. La salvación, por ejemplo, aparecía como el fin principal, pero la iglesia seguía este orden por ser dicha salvación el fin de la existencia humana misma. Es de señalar, pues, que lo único que efectivamente asignaba un destino particular y un lugar especial al matrimonio era la procreación, esto es, el "haber hijos" para darles cristiana educación y que éstos pudieran reconocer a Dios y alabarlo.

Como sabemos, en esta época se identificaban la riqueza y la prosperidad del reino con el florecimiento de su población, es decir, el aumento de familias, vecinos, pobladores, villas y ciudades. A fin de cuentas, la

${ }^{15}$ Viqueira, op. cit., p. 29.

${ }^{16}$ Molina, op. cit., pp. 52 y ss. 
creencia medieval de que Dios creó al hombre para poblar los lugares deshabitados del Paraíso, después de que expulsó a los ángeles caídos con Luzbel $-\mathrm{y}$ que, habiendo interrumpido el pecado original tal propósito, con la muerte de Cristo se había reanudado esta tarea - tuvo mucho éxito entre los religiosos de la Nueva España, sin que a ello se hubieran podido sustraer cronistas de sus órdenes y hombres importantes como fray Jerónimo de Mendieta, fray Juan de Torquemada o fray Vasco de Quiroga, por ejemplo. ${ }^{17}$

Todo ello, junto al mandato bíblico de "Creced y multiplicaos" se conjugó para que el pilar más fuerte sobre el que descansara la explicación eclesiástica del matrimonio fueran la procreación y educación de los hijos. No sucedía lo mismo con el fin de recibir la gracia, dado que ésta era otorgada en cada sacramento.

Otro de los fines, la continencia, iba a ser muy importante porque moldearía alrededor del débito conyugal las relaciones cristianas entre esposos:

Mas usaréis solamente de las mujeres [vosotros los varones] y vosotras, las mujeres, tendréis a sólo vuestros maridos hasta que muráis [...] Porque tú que eres varón te libraras por tu mujer y descansaran con ella tu corazón y tu carne (cuando el demonio te tentare de alguna tentación de lujuria) y de la misma manera, tú que eres mujer, te libraras por tu marido, cuando fueres tentada. Y por tanto os es muy necesario que os obedezcáis el uno al otro, acerca del débito, [según sóis obligados] porque si el uno al otro no os obedeciéredes en esto, cometeréis gran culpa de pecado mortal. ${ }^{18}$

Fue la reflexión sobre el débito conyugal uno de los pocos espacios donde la iglesia reconocía igualdad de derechos y obligaciones para marido y mujer: "...conviene que sepáis que el cuerpo del varón casado por la Iglesia no es ya suyo, sino de su mujer [habida en matrimonio] y el cuerpo de la mujer no es ya suyo, sino de su marido...". ${ }^{19}$

Sin embargo, ésta era la excepción y no la regla. La iglesia nunca dejó de concebir el matrimonio como la unión de dos seres radicalmente distintos. La santificación religiosa de los lazos conyugales era explicada por analogía, como la relación de Cristo [esposo] con su iglesia [esposa] ${ }^{20} \mathrm{El}$ esposo tenía el deber de ayudar a su mujer a alcanzar la salvación, ${ }^{21}$ y por ello la mujer debía someterse a la autoridad del padre, primero, y poste-

${ }^{17}$ Veanse sobre tal tema John Phelan, The Milennial Kingdom of the Franciscans in the New World, Berkeley and Los Angeles, 1956, University of California/Publications in History, vol. 52, 159 pp., y más recientemente Luis Weckmann, La herencia medieval de México, México, 1982, El Colegio de México (2 vols.).

${ }^{18}$ Molina, op. cit., pp. 54-55.

${ }^{19}$ Ibidem, p. 54.

${ }^{20}$ Viqueira, op. cit., p. 30.

${ }^{21}$ Ibidem, p. 46 
riormente, a la del marido. Debía honrarlo, respetarlo y obedecerlo. En esto consistía la ayuda espiritual como otra de las metas del matrimonio:

Porque tú que eres varón, tienes la obligación de ayudar y favorecer a tu mujer en las cosas tocantes a su salvación, provocándola cuanto pudiéredes a vivir santamente: e importunándola a que sirva y obedezca a nuestro Señor Dios, y a la guarda de sus mandamientos, y a que no haga ni cometa ninguna maldad, estorbándola cuando quisiere hacer algún desatino...22

El responsable en el matrimonio era el varón, a despecho de que las mujeres no eran educadas más que para casarse. ${ }^{23} \mathrm{~A}$ no dudar, para la iglesia el poder tenía que ser ejercido por el varón. En la ceremonia modelo de Molina el sacerdote interrogaba a la novia sobre si tenía hijos y si había estado casada anteriormente. Esto era, desde luego, algo previo a la aceptación de la novia por parte del hombre:

...Porque conviene que el varón sepa muy bien la calidad de la persona con quien se casa, si es esclava o viuda, o si, por ventura, tiene hijos, o si es virgen y doncella, o de mucha edad y vieja...24

Es claro que las normas eclesiásticas pretendían regular, no sólo la ceremonia nupcial, sino también la vida cotidiana misma de las parejas y familias cristianas. La mayor parte de las normas sobre las relaciones conyugales y hogareñas se derivaban de la concepción eclesiástica sobre el matrimonio, la cual entrañaba, como veremos más adelante, propuestas éticas que implicaban ciertos comportamientos que hoy día se han dado en llamar demográficos.

\section{El perfil ideal de todo novio y toda novia}

El ímpetu eclesiástico por dominar y regir la ceremonia civil del matrimonio se consolidó, en el periodo que nos atañe, en una compleja y complicada red de normas y recomendaciones sobre algunos requisitos que debían cumplir los futuros cónyuges para casarse. Éstos incluían lo mismo recomendaciones sobre la edad ideal para contraer nupcias, que estrictas prohibiciones sobre la injerencia de terceras personas en el libre consentimiento de los contrayentes, por ejemplo; un singular interés tuvo en esta regulación la reflexión eclesiástica sobre la edad a la que debían unirse en matrimonio los jóvenes.

Como se sabe, tanto el derecho canónico como el civil coincidían en

${ }^{22}$ Molina, op. cit., p. 55.

23 Pilar Gonzalbo Aizpuru, "Tradición y ruptura en la educación femenina del siglo xv1", mecanografía PIEM/Colmex, México, 1984, pp. 5 y ss.

${ }^{24}$ Molina, op. cit., p. 46. 
fijar la edad mínima en catorce años para el varón y doce para la mujer. ${ }^{25}$ La falta de edad constituía un impedimento dirimente dentro del derecho canónico para contraer nupcias, es decir, que el enlace llevado a cabo por un menor de catorce años y/o una menor de doce quedaba sencillamente anulado para la iglesia. A menudo se piensa que la regulación eclesiástica estaba intentando solamente fijar las edades mínimas per misibles, sin que ello implicara, necesariamente, que el deseo de teólogos y canonistas estuviera centrado en que los jóvenes contrajeran nupcias lo antes posible. Sin embargo esto no es así, pues para la iglesia católica las edades mínimas eran también las más deseables; las más convenientes.

Como hemos visto, la continencia era uno de los propósitos hacia los que debía encauzarse el matrimonio, pues de este modo se buscaba evitar que los fieles despeñaran su alma cometiendo pecados mayores o se enlodaran en la sexualidad adquiriendo costumbres perniciosas. Recuérdese que lo mismo era pecado fornicar realmente que tener el deseo de hacerlo. Por ello, el despertar de la sexualidad en los adolescentes no podía ser visto, sino como el peligroso despertar de los sentidos y la tentación.

El matrimonio era el mejor antídoto para mitigar -en los célibes no religiosos- las flaquezas de la carne y poder seguir sirviendo a Dios. ¿Qué mejor manera para proteger a doncellas y mancebos de la concupiscencia que el casarlos cuanto antes bajo las normas permitidas y reduciendo al mínimo su potencial desenfreno sexual? No olvidemos que - según el derecho canónıco- el impedimento dirimente de edad dejaba de serlo cuando "la malicia supla la falta de edad". ${ }^{26}$

Otro elemento importante a considerar es el hecho de que el enlace eclesiástico no estaba instituido, sino para la procreación y educación de los hijos: ¿cabe pensar, entonces, que los jóvenes estaban listos para casarse al momento en que estaban aptos para procrear? Tal parece el razonamiento que llevó a la iglesia a impulsar una muy temprana edad al matrimonio; a pugnar porque se produjeran los casamientos lo antes posible.

Fray Juan de Zumárraga, lo mismo que Josep de Acosta, crefa conveniente casar a los indios lo antes posible, a fin de que se evitaran amancebamientos y otras ofensas a Dios. ${ }^{27}$ En los monasterios dedicados a la educación de las niñas que se propuso instalar para albergar a las hijas de los indios, Zumárraga buscaba que las niñas entraran "desde seis o siete años abajo, para que sean criadas, doctrinadas e industriadas [...] y que, llegadas a los doce años se desposen con los muchachos que se crían en los monasterios". ${ }^{28}$ Por otra parte, las edades de catorce y doce años para

${ }^{25}$ Daisy Ripodas Ardanoz, El Matrimonio en Indias: realidad social y regulación jurídica, Buenos Aires, 1977, FECG, 454pp. (En especial p. 97.)

${ }^{26}$ Ibidem, p. 94.

${ }^{27}$ Ibidem, p. 100.

${ }^{28}$ Gonzalbo, op. cit., p. 8. 
varón y mujer respectivamente son reiteradamente señaladas por los confesionarios que consultó Viqueira. ${ }^{29}$ En el "Confesionario Mayor" de Molina no se encuentra la excepción:

...que sean preguntados de la edad que han y tienen los que se quieren casar; conviene a saber qué años tienen, porque el varón para poder contraer matrimonio con su mujer, conviene que tenga catorce años de edad, y la mujer doce. $^{30}$

Pese a ser ésta la opinión dominante no fue, empero, la única, pues había quien - dentro de la iglesia - sostenía que a tan tempranas edades los jóvenes esposos estaban capacitados para procrear, mas no para educar cristianamente a los hijos, ni aun para llevar santamente la vida marital. El arzobispo de Guatemala -Cortés y Larraz- escribía que:

...junto con la edad mínima requerida los naturales no suelen alcanzar la suficiente discreción como para tomar estado [matrimonial], y de esto se originan repudios, adulterios y mola crianza de los hijos. ${ }^{31}$

Lo mismo pensaba fray Diego de Landa para sus adoctrinados de Yucatán, haciéndose asistir -además- de la costumbre maya de casarse a los veinte años. ${ }^{32}$ Tal partido parece haber encontrado eco en la prohibición del III Concilio Provincial Mexicano a los matrimonios con por lo menos un menor, bajo pena de excomunión a los responsables. ${ }^{33}$ Sin embargo, ésta parece haber obedecido más a la preocupación de la iglesia por desterrar la costumbre precolombina de concertar entre los padres de los novios, la boda desde que éstos eran pequeños, que a un intento por elevar el límite inferior de la edad a la primera unión eclesiástica, ya que, en seguida de la prohibición referida estaba la orden expresa de los párrocos de no asistir a las bodas típicas nativas que se expresaban "por palabras de futuro". ${ }^{34}$

Con todo, dicha posición no parece haber tenido mayor éxito entre regulares y seculares de la América española, excepción hecha por la experiencia de la Compañía de Jesús en el Paraguay:

29 Viqueira, op. cit., p. 29.

30 Molina, op. cit., p. 54 (el subrayado es mio).

${ }^{31}$ En Ripodas, op. cit., p. 100.

32 Ibidem, p. 100

${ }^{33}$ III Concilio Provincial..., op. cit., p. 346.

${ }^{34}$ Ibidem, p. 346. Sobre las costumbres prehispánicas matrimoniales existen varias relaciones - sobre todo franciscanas-. Véanse las obras de fray Bernardino de Sahagún, fray Jerónimo de Medieta y fray Juan de Torquemada. La diferenciación entre el ritual nativo de casar por "palabras de futuro" y el católico - "por palabras de p"esente"- se puede encontrar en Sergio Ortega [ed.J, op. cit., en el ensayo correspondiente a Ortega Noriega. 
Una aspiración semejante sólo se cumple en forma sistemática en el ámbito circunscripto de las misiones jesuíticas del Paraguay. En ellas se aumenta de ordinario en tres años la edad mínima requerida en derecho: si, a juicio del Superior, no hay motivo para anticipar el sacramento, los matrimonios de los guaraníes se efectúan cuando los varones tienen diecisiete años y las mujeres tienen quince. El propósito [...]: esperar a que los novios hayan alcanzado madurez para su nuevo estado... ${ }^{35}$

Nótese que, aún en sus "extremos", la iglesia recomienda en la mujer una edad no mayor de los quince, lo que sin duda habla en favor de la tésis según la cual la edad mínima es la edad ideal. Molina, incitando al mejoramiento de la confesión, le pedía al confesado que hiciera memoria de sus cuatro edades:

Conviene que comiences desde tu niñez a traer memoria de tu vida, conviene a saber desde que eras de tierna edad y tenías algún conocimiento y usabas de razón, qué es lo que cometiste, y también desde que eras mancebo y desde que eras de perfecta edad y hasta tu vejez, en que has ofendido a Nuestro Señor. ${ }^{36}$

Parece muy probable que el mancebo fuese identificado con lo que hoy se conoce como adolescente, entre la "tierna edad" y la "perfecta edad", entre la blanca inocencia y el reposado sosiego. ¿No era entonces el mancebo quien mayores riesgos corría de pecar ante su propio cuerpo y el de otras doncellas y mancebos como él? El mismo pecado del amancebamiento ¿No constituía una clara asociación [a-mancebarse] entre la cohabitación fuera de las normas determinadas por la iglesia y la edad transitoria entre niñez y madurez? ¿Era la edad de los pecadores la diferencia entre el amancebamiento y el amasiato? Una pregunta más interesante -según creo- sería el explicar no cómo podría la iglesia haber estado en pro del matrimonio temprano, sino cómo hubiera podido dejar de apoyarlo.

Un segundo aspecto en el que confesores y canonistas trataron de hacer obedecer la palabra de la iglesia sobre la constitución matrimonial de la pareja fue el del parentesco y sus prohibiciones.

Como se sabe, el impedimento de nupcias por parentesco era también de carácter dirimente, es decir lo suficientemente grave como para anular el matrimonio contraído dentro de la prohibición. El derecho canónico consideraba incestuoso el matrimonio entre parientes cercanos. El parentesco podía ser de tres tipos: consanguíneo, es decir, el vínculo que une a personas que son o se reputan descendientes de un tronco común; por afinidad, o sea el vínculo nacido del matrimonio o la cohabitación ilícita entre la mujer y los parientes consanguíneos del hombre, y entre el hom-

${ }^{35}$ Ripodas, op. cit., p. 101.

${ }^{36}$ Molina, op. cit., p. 91. 
bre y los parientes consanguíneos de la mujer; y por último el parentesco espiritual, que era el vínculo contraído en la confirmación o en el bautizo entre los padrinos y los padres del ahijado y entre los padrinos y el ahijado mismo.

Flandrin ha observado ${ }^{37}$ que fue la obsesión permanente entre los teólogos por uno de los pecados sexuales más graves -el pecado del incestolo que llevó a la iglesia a prohibir terminantemente los enlaces entre parientes consanguíneos hasta el cuarto grado inclusive; entre parientes por afinid ad matrimonial también hasta el cuarto grado inclusive, y ențre parientes espirituales en el único grado que se podía dar, o sea el primero. Conviene observar que los grados de parentesco se computan de la misma manera, sea cual fuere el carácter de este último.

Por considerar complicada en su exposición la computación canónica de los grados de parentesco, creemos pertinente la transcripción de las reglas elementales para distinguir a los parientes en los primeros cuatro grados:

El derecho canónico asigna tres reglas para la computación de grados de consanguinidad. Primera regla para la línea recta. En línea recta, son tantos los grados, cuantas son las generaciones, a contar desde el tronco, o lo que es lo mismo, cuantas son las personas, excluyendo el tronco: así, el hijo está en primer grado, el nieto en segundo, el bisnieto en tercero, etcétera.

Regla segunda para la línea transversal igual. En esta línea, dos personas distan entre sí en el mismo grado en que cada una de ellas dista del tronco común: así, distando dos hermanos un solo grado del tronco común, distan uno solo entre sí, y por consiguiente, está en primer grado de la línea transversal igual; por la misma razón, los primos hermanos están en el segundo grado, los hijos de primos hermanos, en el tercero, y los hijos de los hijos de primos hermanos, en el cuarto.

Regla tercera para la línea transversal desigual. En esta línea, dos personas distan entre sí los mismos grados que dista del tronco común la línea que está más distante de éste: así, el tío y el sobrino, de los cuales el primero dista un solo grado y el segundo dos del tronco común, están entre sí en el segundo grado. $^{38}$

No se debe menospreciar la firmeza con que la iglesia buscó hacer que se obedeciera tal prohibición. La creación de registros parroquiales continuos sobre matrimonios y las informaciones matrimoniales del provisorato eclesiástico se deben, en buena medida, a la preocupación eclesiástica por no avalar nupcias protagonizadas por cónyuges que estaban emparentados en los grados vedados. A menudo, la difícil comprensión

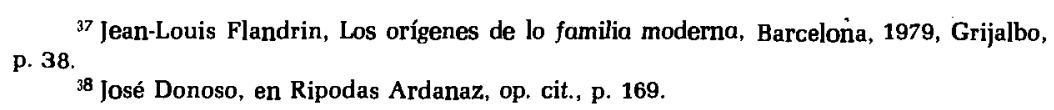


de la computación canónica impide visualizar los alcances de la prohibición, pero en realidad ésta abarcaba a muchas personas que, en la vida cotidiana de comunidades pequeñas y aun de villas y ciudades, aparecían ante los ojos del común como doncellas y mancebos perfectamente viables, desde el punto de vista económico y social, para esposarse entre sí. Por ilustrar con ejemplos, una persona no podía casarse con sus primos hermanos (los hijos de los hermanos de su padre y/o madre), ni con sus primos segundos (los hijos de los primos hermanos de su padre y/o madre), ni con sus primos terceros (los hijos de los primos segundos de su padre y/o madre) ni con sus primos cuartos (los hijos de los primos terceros de su padre y/o madre). Esto sólo computando los grados en la línea transversal igual. $O$ por decirlo en otra forma, siguiendo la línea ascendente, no podía haber casamiento entre personas que tuvieran desde un tatarabuelo en común. En esta actitud de rigor, un viudo tenía impedido tomar esposa entre cualquiera de sus parientes hasta el cuarto grado, y además tenía vetadas a todas las mujeres parientes de su mujer finada hasta el cuarto grado también. Exactamente lo mismo, pero a la inversa, sucedía con las viudas y los parientes de sus finados esposos.

Desde luego que en pequeñas villas y en pueblos de indios, donde todos estaban entrelazados por algún parentesco y de entre tales vínculos los más se ubicaban en los primeros grados, nadie se podía casar - con dicha legislación-sin incurrir en nupcias incestuosas. Además, como es obvio, los indígenas tenían formas de concretar la prohibición del incesto muy distintas de las eclesiásticas occidentales, razón por la cual para confesores y párrocos era un verdadero vía crucis llegar a conocer el parentesco y sus grados existentes en cada pareja solicitante. Por todo ello la iglesia, no antes de muchas vacilaciones, decidió relajar un poco la norma para los casamientos entre indios, y así en 1537 Paulo III ${ }^{39}$ concedió a los indígenas emparentados en tercer grado de consanguinidad o afinidad licencia para matrimonio, influyendo decisivamente en esta decisión el hecho de que se trataba de cristianos nuevos, así como el reconocimiento eclesiástico de que -dados los recursos con que se contaba en la época de oro de la iglesia indiana- existían verdaderas dificultades para garantizar el apego estricto a la norma. ${ }^{40}$

Desde entonces para los indígenas fue permisible la unión entre por lo menos primos segundos sin necesidad de tramitar un permiso especial. De igual privilegio gozaron los negros, ${ }^{41} \mathrm{si}$ bien mestizos y castas no par-

\footnotetext{
${ }^{39}$ Ripodas Ardanaz, op. cit., p. 171.

40 Por citar un ejemplo: la iglesia -en el contacto inicial- se formuló de muy diversas maneras - que nunca terminaron por resolver satisfactoriamente el problema-cuál de las esposas que tenia el cacique a la llegada de los españoles era la esposa verdadera. La junta apostólica de 1524-1525 para la Nueva España tuvo pareceres distintos e incluso antagónicos, los cuales finalmente no llevaron a ningún acuerdo. Véase Concilios Provinciales..., op. cit., pp. 1-5. 41 Ripodas Ardanaz, op. cit., p. 187
} 
ticipaban de la dispensa original, aunque siempre encontraron a ese respecto en la iglesia una actitud vacilante, cuando no francamente acomodaticia.

En 1585 Gregorio XIII los incluía en el privilegio paulino, pero en 1690 Alejandro VIII ordenó que las dispensas no les fueran concedidas con la misma facilidad que a los indios. Para los españoles en cambio - y sin duda porque se trataba de cristianos viejos- no había ninguna dispensa, exceptuando el caso de que el matrimonio tuviera que llevarse a cabo forzozamente para reparar la honra mancillada de alguna mujer. En tal situación el obispo podía otorgar la dispensa. ${ }^{42}$

En Nueva España la situación quedó regulada por el II Concilio Provincial Mexicano de 1565, el cual ordenaba acatar las disposiciones tridentinas, y ya en forma expresa por el III Concilio Provincial Mexicano en $1589 .{ }^{43}$

Para todos los no indios y no negros, consiguientemente, quedaban prohibidos los enlaces entre parientes consanguíneos hasta el cuarto grado inclusive; entre parientes por afinidad lícita (la cópula matrimonial) hasta el cuarto grado inclusive; entre parientes por afinidad ilícita (la cópula extramarital) hasta el segundo grado inclusive; y entre parientes espirituales. ${ }^{44}$

$\mathrm{Si}$, por un lado, la instrumentación de la norma para los indígenas y los negros nos revela que la iglesia buscaba evitar un confrontamiento abierto con las solidaridades familiares que ponían en marcha los habitantes del reino, al buscar casamientos dentro de la parentela, por el otro no se puede negar que la iglesia procuró, a toda costa, que en ninguno de los grupos raciales estas alianzas y compromisos, verificados en el interior de la etnia, se reforzaran demasiado.

El II Concilio Provincial Mexicano ordenaba a clérigos, rectores y eclesiásticos del Arzobispado: “... que cuando hubieren de celebrar el sacramento del Bautismo no reciban por padrino más de un compadre y una comadre, so pena de tres pesos de minas." 45

La prohibición por cognación espiritual, por otra parte, no obstante que era la que menos candidatos descartaba, era la única posible de evitar sin la venia de la iglesia, pues sólo bastaba con escoger por padrinos a parientes cercanos, afines o de sangre, o bien al propio párroco de la feligresía.

Molina, lo mismo que los confesores contemporáneos, ${ }^{46}$ puso especial interés en detectar por medio de la confesión matrimonios prohibidos en el grado y parentesco que fueren:

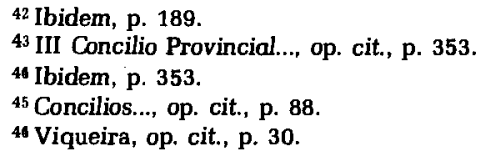


...que sean preguntados [los contrayentes] si son - por ventura-entre sí deudos o parientes, examinándolos bien acerca del parentesco que se han, porque nadie se case con su hermano, en los mismos grados, ni con su cuñada, ni con su tío o tía, ni con su compadre o comadre [que tuvo a su hijo en el baptismo o en la confirmación] de manera que declaren cualquier impedimento que tuvieren. ${ }^{47}$

En la ceremonia la misma pregunta era hecha varias veces al fiscal, al escribano, y sobre todo a los parientes y conocidos de los novios, haciéndoseles ver que la excomunión era una pena muy grave y que se aplicaria inflexiblemente a quien llevara a cabo o siquiera ocultara tales anomalías. $^{48}$

El último de los requisitos eclesiásticos para contraer nupcias que interesan a nuestros propósitos es el del libre consentimiento. Si las prohibiciones de parentesco son, 'en resumidas cuentas, una propuesta clara a la exogamia étnica -en los indios limitada, en españoles y castas tajante- la requisitoria del libre consentimiento es una abierta insinuación de la iglesia a sus feligreses para que se casen con quien quieran y puedan, o bien, para que impidan toda boda arreglada si la pareja en turno no responde a sus intereses individuales. La iglesia se opuso terminantemente a las bodas llevadas a cabo por arreglos extrafamiliares, y atacó con todos sus medios a caciques, magistrados y miembros del común que tenían por costumbre el concertar a su arbitrio los matrimonios de macehuales, criados, peones y lacayos bajo su cargo.

El libre consentimiento es uno de los puntos de las normas matrimoniales donde menos disparidades se observan en las distintas esferas de la política eclesiástica, lo mismo a nivel del Concilio de Trento y los concilios provinciales, que a la altura de los confesionarios particulares elaborados por regulares:

El Cristianismo innovó en Occidente al hacer del matrimonio una unión libre y voluntaria. La decisión de casarse debían tomarla los futuros esposos, libres de toda presión familiar. La Iglesia se oponía así a todos los casamientos que se hiciesen por arreglos entre los padres y en contra de la voluntad de los novios. Varios de los confesionarios en lenguas indígenas, o bien se preocupan porque los novios que van a contraer matrimonio lo hagan por voluntad propia, o bien advierten a los padres que no obliguen a los hijos a casarse contra los. deseos de estos últimos. 49

En el confesionario de Molina aparecía la pregunta expresamente di-

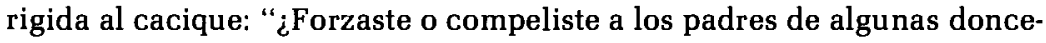

${ }^{47}$ Molina, op. cit., p. 55.

48 Molina, op. cit., pp. 54 y ss

49 Viqueira, op. cit., p. 30. 
lias a que las casásen con tus criados y mozos de casa?"50 Y es que los confesores tenían muy claro que en una boda donde se forzaba a uno y/u otro cónyuge al casamiento existían pocas posibilidades de convertir al matrimonio en un eficaz instrumento de salvación, amén de que las razones que orillaban a caciques y familiares adultos, en general muy poco tenían que ver con las cuestiones espirituales.

Concertar un enlace por amasar una fortuna, por no dividir un patrimonio, por conservar un esclavo, por asegurar una próspera alianza o por no perder a una mujer en el servicio doméstico, era algo - a los ojos de la iglesia-demasiado terrenal y peregrino. Recuérdese que no casarse por amor a Dios, no enderezar hacia él el sacramento del matrimonio era simplemente ayuntarse como las bestias, o cuando mucho, como los infieles.

Ahora bien, no debe pensarse que las autoridades eclesiásticas pretendían socavar la autoridad paterna sobre los hijos. Hemos visto que la autoridad que el marido ejercía sobre la mujer tenía su antecedente en el dominio del padre sobre los hijos; tales relaciones guardaban mucha similitud -en términos de los papeles activo y pasivo en la lucha por la salvación-con la autoridad de un pastor espiritual sobre sus ovejas parroquianas, del rey mismo sobre sus súbditos y del propio Dios con sus criaturas. ${ }^{51}$

La pretensión eclesiástica gira más bien en torno a la regencia del lugar donde se constituye la pareja - no necesariamente la familia-, y para tales fines la iglesia buscó más reforzar la autoridad paterna que intentarlo prescindiendo de ella.

No olvidemos que el Concilio de Trento, al decretar la excomunión ipso facto de quienes obstaculizan el libre consentimiento, sólo menciona a "señores temporales", es decir hombres con algún rango de reconocida jurisdicción política, no familiar.

CAPÍTULO X. Nada dispongan contra la libertad del matrimonio los señores temporales.

Con tanto grado llegan a cegar muchas veces las pasiones y la codicia la inteligencia de los señores temporales y de los magistrados, que obligan con amenazas y castigos a hombres y a mujeres que viven bajo su jurisdicción, en especial a los ricos o a los que esperan grandes herencias, a contraer matrimonio contra su voluntad con aquellas personas que los señores o magistrados les designan.

Por consiguiente, siendo en extremo detestable atentar contra la libertad del matrimonio, y que provengan injurias de los mismos de quienes se espera justicia, manda el Santo Concilio a todos, de cualquier estado, condición o dignidad que fueren, bajo pena de excomunión en que incurririan ipso facto, que

${ }^{50}$ Molina, op. cit., p. 44

51 La exposición más acabada sobre el carácter análogo de estos vínculos se encuentra en Flandrin, op. cit., capítulo 1. 
de ningún modo obliguen, directa o indirectamente, a sus súbditos ni a nadie, a contraer matrimonio contra su voluntad. 52

Por las mismas razones se decretaban nulas las uniones entre raptor y raptada, ${ }^{53}$ sin que esto significase, en modo alguno, que la iglesia buscara que sólo los contrayentes intervinieran en la decisión de esposarse. De hecho el libre consentimiento existía si un casamiento concertado por terceros era aceptado por los futuros esposos. La iglesia no dejó de reconocer un derecho de los padres sobre los hijos en las nupcias de estos últimos. Lo que se buscaba era que los padres, al arreglar el matrimonio, pensaran más en la salvación de su familia y en la de ellos mismos que en buscar riquezas, tan lisonjeras como vanas o deleites tan breves como engañosos. Nada raro debe parecer, entonces, que se luchara por el libre albedrío de los novios contra sus señores, y se buscara al mismo tiempo que los padres procuraran que para el enlace se tomara en cuenta, esencialmente, la salvación del alma.

Molina dirigía esta pregunta al padre de familia:

¿Dejaste - por ventura- de enseñar la doctrina y las palabras de Dios a tus hijos y a leer y escribir? ¿O quizá no tienes cuidado de ellos ni los haces trabajar y entender en alguna cosa? ¿O quizá los has hecho perezozos con tu pereza? ¿O por ventura no has tenido cuidado de casarlos (siendo de edad) y a esta causa se amancebaron y ofendieron a Dios nuestro señor? Y cuando te pidieron en casamiento a tu hija ¿Entregástesela luego al que te la pidiá [antes’que la casásen por la iglesia] y ordenaste que luego se fuese con él a su casa, antes que les tomáse las manos el sacerdote y les dijése misa y les veláse ${ }^{54}$

El padre era responsable de los pasos de sus hijos por lo menos hasta que se casaban: "Y cuando en tu presencia cometieron algún pecado tus hijos, amancebándose (...) ¿Dejaste de castigarlos y corregirlos no enmendando ni los corrigiendo como eras obligado?" 55

Las baterías de teólogos y confesores se dirigían también a lọ señores poderosos y sus malas mañas, y en contra de los caciques y sus perjudiciales costumbres.

De otra parte, Tomás de Sánchez defendía el consejo paternal, aunque basándolo más en la piedad filial que en la patria potestad. ${ }^{56}$ Así se buscó evitar que los encomenderos, por ejemplo, forzaran a sus tributarios a casarse entre sí para no perder brazos en la mina, la labor, la casa o el trapiche. En este sentido el III Concilio Provincial Mexicano mandó

\footnotetext{
52 Vargas Machuca, op. cit., p. 312.

${ }^{53}$ Ibidem, p. 312.

54 Molina, op. cit., p. 99.

55 Ibidem, p. 99.

${ }^{56}$ En Ripodas Ardanaz, op. cit., p. 260.
} 
- so pena de anatema- que "de ninguna suerte" se obrara contra el libre matrimonio, ${ }^{57}$ disponiéndose, además que a los esclavos casados no se les separara - esposo de esposa - en lugares muy distantes entre sí: "que no podrán cohabitar con sus mujeres por largo tiempo. Y se deja a decisión del ordinario el tiempo que se ha de reputar largo." 58

Tanto el segundo como el tercer concilio provincial mexicano prohibían terminantemente la venta de mujeres entre los indios, además de insistir en que el cacique no tenía ninguna facultad para repartir las mujeres. ${ }^{59}$ De ahí que obligar a una persona a casarse contra su voluntad era tan ilícito como impedir que se casara con quien deseara. En Nueva España existía la pena de treinta días de prisión a quien violara la regla de cualquier forma. ${ }^{60}$

Ahora bien, el despojar a los señores temporales de las repúblicas particulares (de indios y de españoles), ¿no es buscar un patrón de nupcias integrador? Restringir la decisión a la conciencia cristiana de padres e hijos en busca de su salvación espiritual, ¿no es propugnar porque en la distribución de mujeres prive el universalismo cristiano sobre las particularidades étnicas y mundanas? ¿O es que se puede hablar de fuertes prohibiciones intraétnicas y libre consentimiento sin pensar en la mezcla racial que el seguimiento de tales normas conlleva? ¿No sería más fácil que las costumbres idólatras y las creencias equivocadas de indígenas y judaizantes se perpetraran sin ser descubiertas a causa de que los matrimonios en tales grupos fueran férreamente endogámicos?

No estamos pensando que el mestizaje haya sido el legítimo vástago de la idea de igualdad de las almas predicada por la iglesia, sino que la propuesta eclesiástica subyacente en la ética matrimonial católica estaba definitivamente por los matrimonios mixtos, tratándose, a nuestro parecer, de un conflicto de prestigio entre las instituciones novohispanas. En el matrimonio, la iglesia trata de demostrar que su poder es mucho mayor que el de un encomendero, comerciante, minero, cacique o hacendado, pues mientras que éstos sólo pueden donar mujeres de su coto exclusivo, aquélla pretende erigirse como la donadora de todas las mujeres, dominar por entero los patrones de enlace a través de la desaparición de hábitos y costumbres particulares en castas, indios y españoles.

El problema es cómo regir la circulación de mancebos y doncellas. La prohibición del incesto funciona como un descarte de privilegios internos de los señores temporales, y la historia del matrimonio es la historia de la lucha por regir tal espacio.

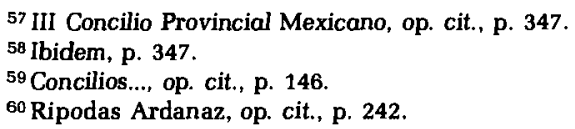




\section{Las relaciones conyugales}

La iglesia buscó que, dados los fines del matrimonio, existiera consistencia entre la búsqueda general de la salvación y la regulación particular sobre la vida marital cristiana, procurando diseñar ésta de tal suerte que en ningún momento contraviniera los principios generales de aquélla, siendo el amor a Dios, la salvación eterna y la procreación de los hijos los ejes sobre los que la iglesia edificó la ética de las relaciones conyugales de los hogares católicos. Para ello, teólogos, moralistas y confesores trabajaron arduamente en la elaboración de reglas y recomendaciones a seguir por los fieles, así como penitencias y castigos para los pobres de espíritu.

En el presente capítulo se enunciarán sólo aquellas reglas que, a nuestro juicio, contienen subyacentes ciertas propuestas sobre comportamientos demográficos en nupcialidad y fecundidad.

Como hemos visto, los fines secundarios del matrimonio eran la ayuda espiritual y corporal que los cónyuges se debían brindar mutuamente. Debemos añadir que, pese a lo señalado de que la mujer era incapaz de alcanzar la salvación -estándo dentro del matrimonio- sin la ayuda del esposo, ${ }^{61}$ en el material que hemos consultado no se encuentran fundamentos pára tal aseveración, aunque es innegable que el esposo tiene el reconocimiento eclesiástico para ejercer la tutela de su mujer.

Para fray Alonso de Molina, la mujer está tan obligada como el hombre a procurar la salvación de su pareja, sin que ello significara, desde luego, que la autoridad dejara de recaer en el varón:"62 "Porque tú que eres varón tienes obligación de ayudar y favorecer a tu mujer en las cosas tocantes a su salvación [...] y la misma obligación tienes tú que eres su mujer, de favorecerle y ayudarle a salvar." El varón debía trabajar fuertemente para mantener a su mujer e hijos, y además, para socorrer a pobres, enfermos y gente necesitada. Pero ante todo debía querer bien a su mujer, no abandonarla y colaborar con ella en la crianza de los hijos. No maltratarla ni importunarla, no excederse en sus mandatos y apoyarla en ciertos momentos:

[preguntas para el casado]

¿Amas y quieres bien a tu mujer, favorécesla en sus trabajos y necesidades y en el tributo?

¿Consuélasla cuando está triste, afligida y muy angustiada?

Y cuando te enojaste sin razón o estabas borracho, o algo caliente, ¿Afligiste-

la, entristecístela o maltratástela? ${ }^{63}$

${ }^{61}$ Viqueira, op. cit., p. 49.

62 Molina, op. cit., p. 56.

63 Ibidem, p. 29. 
La mujer por su parte debía respetar, honrar y obedecer a su esposo, cumplir con las faenas del hogar y sobre todo criar a sus hijos, en el sentido de alimentarlos y educarlos cristianamente. En cuanto al amor conyugal, podía considerarse como un sentimiento secundario, cuando no peligroso, para el buen funcionamiento de la relación, tomando en cuenta que el respeto y la obediencia eran de mayor trascendencia. El deseo carnal entre los cónyuges era francamente nocivo para la vida marital católica y una de las mejores oportunidades que tenían los esposos para perder sus almas.

Ambos tenían la obligación de cuidar del otro cuando estuviere enfermo, lo cual -en el caso de la mujer- no implicaba que tuviera que desatender sus demás tareas: ${ }^{64}$

Y el mismo cuidado ha de tener la mujer para ayudar a su marido: porque es obligada a guardarle la hacienda, a estar en casa y a barrer, lavar y fregar, a hilar y tejer, moler y guisar de comer, criar a los hijos y a tener gran cuidado de su marido [cuando enfermáre] consolándole y ocupándose en su servicio y honrándolo mucho. Y la misma obligación tiene el varón de tener gran cuidado de su mujer [cuando estuviere enferma] buscando las medicinas y llamando al médico: y guisándole de comer, importunándola mucho a que coma el manjar, y regocijándola y tratándola bien -especialmente cuando estuviere preñada- y honrándola mucho.

Sin embargo el faltar a alguna de estas recomendaciones no significaba, en modo alguno, apartar un lugar en el infierno o el purgatorio, pues las penitencias y castigos que anunciaba la iglesia para este tipo de infractores no se asemejaban a las correspondientes a un pecado mortal. Por ello se podría decir que el buen trato y la reciprocidad de obligaciones eran recomendadas en muy pocos casos, entre los cuales cabe destacar el de gravidez en la mujer.

No eran tan laxas las normas eclesiásticas cuando trataban las relaciones sexuales entre los casados. Ahí la iglesia, a través de su conceptualización del débito conyugal, imponía tajantemente, y en igualdad de condiciones, el derecho del cónyuge a disponer del cuerpo del otro en cualquier momento. Se puede decir que el débito conyugal es el único espacio donde la norma reconoce que el hombre le debe obediencia a la mujer y que ambos, estando expuestos al mismo rigor en las penas, detentan la misma autoridad y los mismos derechos. Es éste el úiiico lugar donde la mutua responsabilidad matrimonial es equitativa para ambos sexos. El varón no manda sobre su cuerpo, sino que éste pertenece a la mujer, al tiempo que el cuerpo de la esposa es pertenencia exclusiva del marido, en tratándose, por supuesto, de relaciones sexuales. La iglesia se muestra tan estricta en dicha

${ }^{64}$ Ibidem, p. 57 
norma que los pecados derivados de una negación de cumplir tal obligación, por parte de cualquiera de los cónyuges, involucran en el mismo grado al pecador y al esposo que rehusó cohabitar: ${ }^{65}$

Porque tú que eres varón te librarás por tu mujer. Y descansará con ella tu corazón y tu carne [cuando el demonio te tentáre de alguna tentación de lujuria]. Y de la misma manera tú que eres mujer te librarás por tu maridó cuando fueres tentada. Y por tanto os es muy necesario que os obedezcáis el uno al otro, el uno al otro acerca del débito (según sois obligados). Porque si el uno al otro no os obedeciéredes en esto, cometeréis gran culpa de pecado mortal y ofenderéis gravemente a nuestro señor Dios. Por cuanto con tal desobediencia se ponen en grandes peligros de sus ánimas, los que son casados por la iglesia: Porque cuando, sin alguna justa causa, resiste la mujer a su marido, negándole el débito, le da motivo a que se amancebe y se enoje: y que menosprecie y desampare a su mujer: y a se desatinar. Y este desatino y turbación del varón, y todos sus amancebamientos, irá a pagar y a estar su mujer al infierno: y la razón es porque lo provocó y fue ocasión de ofender a nuestro señor Dios. $Y$ al contrario, si el varón no condescendiere y obedeciere, en este caso, a su mujer, negándole el débito, se despeñará también en el infierno [...] y acerca de la obediencia que el uno al otro os debéis en pagar el débito, conviene que sepáis que el cuerpo del varón: casado por la iglesia, no es ya suyo, sino de su mujer [habida por matrimonio] y el cuerpo de la mujer no es ya suyo, sino de su marido..

En aras de encauzar la lujuria de los casados siempre hacia sus respectivos esposos, se prohibió que cualquiera de éstos pudiera rehusar cumplir con su parte sin causa justificada. Desde luego que las vigilias del calendario litúrgico estaban por encima del débito conyugal, es decir, éste no podía ser requerido en tales fechas; lo mismo sucedía en caso de enfermedad de alguno de los esposos, o bien, en algunos casos de embarazo, toda vez que siendo la progenie el fin principal del matrimonio, es de esperar que las normas sobre relaciones conyugales se preocuparan por regularlas aun en los periodos de embarazo, en los cuales el esposo debía cuidar a la mujer y, sobre todo, proteger al producto, quien tenía, antes de nacer, privilegios sobre su futura madre. Para Molina, por ejemplificar, un moribundo que tenía a su mujer encinta: "Ha de dar toda su hacienda al hijo que está en el vientre de su mujer". ${ }^{66}$

Aunque las relaciones sexuales durante el embarazo eran infecundas, y por lo tanto desatendían el objetivo primordial del matrimonio, la iglesia las aceptó a regañadientes, pensando, sobre todo, en evitar a toda costa el adulterio y la fornicación. No obstante, tales relaciones siempre fueron vistas con mucho recelo por los confesores, quienes sospechaban que, durante el embarazo y la regla, los esposos recurrían a los ayuntamientos

65 Ibidem, pp. 57 y ss.

${ }^{66}$ Ibidem, p. 61 . 
llamados deshonestos, los cuales estaban, por lo demás, prohibidos severamente.

Molina preguntaba a las mujeres casadas:

Cuando estás con tu costumbre ¿Requieres a tu marido para que tenga parte y ayuntamiento contigo?

¿Fue en el vaso ordenado para la generación aquel ayuntamiento que tuvo contigo o en otra parte?

¿Cuántas veces cometiste este pecado?67

Y lo mismo se preguntaba al esposo:

Cuando estaba con su costumbre tu mujer, ¿tuviste alguna vez acceso a ella? $\mathrm{Y}$ las veces que os ayuntásteis ${ }_{i}$ Es con deshonestidad y no en el debido vaso?68

De esta manera, la vida sexual marital entendida como un medio para la procreación y como el más eficaz instrumento para evitar la fornicación y el adulterio, fue la puerta de entrada a la aceptación eclesiástica del sexo en el matrimonio, aunque es menester puntualizar que tales márgenes estuvieron sumamente restringidos, y que -como bien lo ha señalado Noonan- difícilmente se hacía la distinción entre la debilidad que mostraba el cónyuge, aun estando en su derecho al requerir la satisfacción del débito, y el pecado mortal que, sin duda, entrañaba mantener tales relaciones con excesiva vehemencia. Aun los teólogos más liberales ${ }^{69}$ coincidían en afirmar que amar al cónyuge fervorosamente era pecado mortal.

Santa Brígida ${ }^{70}$ vio en sus "Revelaciones" a un hombre condenándose en el infierno por haber querido a su esposa "demasiado carnalmente", y señalaba que los hombres con esposas bonitas, al igual que las mujeres con esposos apuestos, corrían el grave riesgo de perder sus almas en tal forma y, por ello, debían ser mucho muy cuidadosos.

Todas las prácticas amorosas que no devinieran en procreación, además de las que se llevaban a cabo demasiado fervientemente, fueron prohibidas; la principal razón en las primeras es que eran infecundas y -esto para ambas- que anteponían el placer a la procreación. En tal sentido, cualquier escarceo o juego sexual en búsqueda de placer carnal estaban condenados. Por ello, prácticas como el coito interrumpido o la masturbación eran vistos como severos crímenes.

Noonan señala que los teólogos de la edad moderna (Sánchez, Soto, Ledesma y Liguori) llegaron a legitimar el contacto sexual llamado ample-

${ }^{67}$ Ibidem, p. 35.

${ }^{68}$ Ibidem, p. 35.

${ }^{69}$ Noonan, op. cit., pp. 303-340.

${ }^{70}$ Ibidem, p. 305. 
xus reservatus, al pretender defender la abstinencia dentro del matrimonio cuando la progenie era numerosa ${ }^{71}$ y el padre de familia carecía de recursos para sostenerla, o bien, cuando el elevado número de hijos impedía que sus padres pudieran darles una adecuada educación cristiana. ${ }^{72}$ Sin embargo, este método pasa inadvertido en los confesionarios de Nueva España que hasta ahora han sido estudiados, con lo que ignoramos la difusión diocesana que tuvo dicha aprobación.

La teoría galénica de que durante el coito la mujer segregaba una semilla que, junto con la simiente masculina, daría vida a otro ser, llevó a la iglesia a justificar la prohibición de todo contacto, juego o escarceo sexual del que resultaran desperdiciadas cualquiera de estas dos semillas. ${ }^{73}$ De ahí que la anticoncepción, que volvía inútil la emisión de ambas semillas, estuviera terminantemente vedada, junto con los actos eróticos individuales y colectivos que no culminaban en un embarazo. ${ }^{74} \mathrm{El}$ semen humano, sobre el cual el hombre está en potencia, no fue creado y ordenado sino para la vida humana. Entonces su emisión estéril concierne a la potencial vida del hombre, como género, y es un ataque directo contra ella, tal ataque es lo que hace de la lujuria un pecado mortal. ${ }^{75}$ Según santo Tomás, ${ }^{76}$ el semen es necesario para la propagación de la especie y es menester que sea utilizado sólo en la procreación, para la cual, a su vez, ha sido ordenada la cópula carnal: Desperdiciar el semen masculino y/o femenino es algo contrario al bien de la naturaleza, que no es sino la propagación de la especie. Así las cosas, toda cópula extraconyugal, fértil o estéril, es una segregación desordenada e irresponsable de la simiente humana. Una falta a la especie, a la naturaleza y a Dios. Por tal motivo la iglesia se preocupará por tratar de evitar y reprobar cualquier práctica dirigida a la obtención de placer.

Razón por la cual, los confesionarios incluían preguntas directas sobre conductas como la masturbación o la homosexualidad, preocupándose incluso por detectar y castigar a quienes caían en poluciones nocturnas:

Y si es mujer la que se confiesa pregúntele: ¿Palpaste o trataste las vergüenzas de algún varón? ¿Salió por ésto tu simiente? ¿Palpaste a tí misma o a otra per-

71 Debe tomarse con precaución el adjetivo "numerosa" que, a no dudar, sugiere cantidades distintas en la época moderna a las del siglo $\mathrm{xx}$. Tomás Moro - por ejemplo- recomendaba en su Utopía limitar los nacimientos excesivos, pero su justo medio radicaba entre no menos de diez hijos y no más de dieciséis.

72 Ibidem

${ }^{73}$ Véase Jean-Louis Flandrin, "Mariage tardif et vie sexuelle" en Annales E.S.C. núm. 6, 1972, pp. 1351-1379 (p. 1365).

74 Véase Jean-Louis Flandrin, "Contraception et mariage dans l'Occident chrétien”, en Annales E.S.C, núm. 3, París, 1969, pp. 1370-1389 (p. 1379).

75 Ibidem, p. 1379.

${ }^{76}$ Ibidem, pp. 1379 y ss. 
sona - por deleitarte lujuriosamente- por donde viniste a caer en polución? ¿Pecaste con otra, cometiendo el pecado contra natura?77

Y si era varón el confesante: ¿Caíste en polución durmiendo? ¿Salió tu simiente, pareciéndote que tenías ayuntamiento con mujer? Y después que te despertaste y pensaste en ésto ¿Plúgote? ¿Quizá dijiste: si hubiera sido así lo que sonéé? Porque si ésto dijiste y no te plugó [después de que ya estabas despierto] cometiste pecado mortal. ${ }^{78}$

La "molicie" no era menos preocupante, si se toma en cuenta que involucraba el pecar además con el pensamiento, razón por la cual podía estar conectada con todos los demás crímenes sexuales. Benedicti en Francia -1585- aconsejaba indagar las fantasías eróticas de los infractores: ${ }^{79}$

Et faut bien adviser d'en confesser les circonstances. Exemple: Si quelqu'un comettant ce péché pense avoir à faire ou désire une fermme mariée, outre le péché de molesse, c'est adultère: s'il désire une vièrge, c'est stupre; s'il désire sa parente, c'est inceste; s'il désire une religeuse, c'est sacrilège; s'il désire un masle, c'est sodomie: ainsi la femme a l'endroit des hommes.

Es necesario señalar que no siempre hay claridad sobre el significado preciso de algunos de estos términos usados por la iglesia, ya que parecen haber designado cosas distintas. La "molicie" — por ejemplo- estaba identificada en el antiguo régimen con la masturbación, en tanto que en la antigüedad parece haberse referido a la homosexualidad pasiva ${ }^{80}$ El pecado de Onán, por otra parte, es identificado por los teólogos como el coitus interruptus, mientras que en lenguaje común se usa para nombrar a la masturbación. ${ }^{81}$

La Iglesia identificaba la búsqueda de placer con la esterilidad y las prácticas infecundas, que no eran sino caprichos y fantasías contrarias a la naturaleza, amén de contener tantas suciedades y torpezas para el espíritu como para propiciar que los feligreses que las conocieran ya no quisieran casarse, o bien lo hicieran por perpetuarlas dentro del matrimonio. Para la Iglesia placer y procreación estaban colocados en extremos opuestos, y por esta razón sólo permitía una posición en el coito, la llamada natural, si bien no existió la preocupación por explicar qué era lo que hacía a tal postura "natural", por encima de las contrarias a la naturaleza de las demás.

Las formas de apareamiento no naturales siempre fueron sospecho-

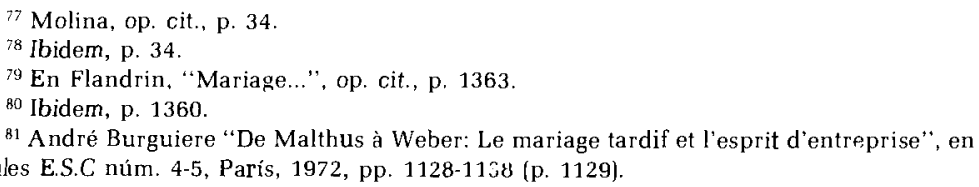


sas de esterilidad, encima de que, por su variedad, no hacían sino despertar o alimentar la lascivia de los esposos. De ahf que se ordenara que la cópula marital siempre fuera de una manera y en el vaso para la generación: este tipo de contacto era lo único de que constaba la obligación conyugal y lo único permisible, en virtud de que las demás formas se reputaban como lujuriosas y anticonceptivas, es decir pecaminosas.

Con todo, la emisión desordenada de la semilla de la mujer y/o la semilla del hombre no era la única forma anticonceptiva castigada, ni siquiera la más penada. La norma eclesiástica prohibía terminantemente el atentar contra la criatura en el vientre de la madre, y ponfa especial atención en prevenir y castigar las acciones que en tal sentido pudieran intentar los futuros padres: usar brebajes o bebedizos para provocar abortos o esterilidades parciales o definitivas eran costumbres que rayaban en la hechicerfa, la brujerfa y el infanticidio. Recuérdese que las infusiones anticonceptivas y abortivas siempre aparecfan descritas junto con venenos, filtros de amor y toda suerte de maleficios. ${ }^{82}$ La iglesia sospechaba en estos delitos especialmente de las mujeres, ${ }^{83} \mathrm{y}$ por ello las preguntas de los confesores a las mujeres en edad reproductiva y mayores eran particularmente meticulosas:

Y si es mujer la que se confiesa dígale el confesor: ¿Bebiste alguna vez brebaje mortffero para echar la criatura por lo cual mataste a tu hijo o fuiste causa de que enfermase? ${ }_{¿} \mathrm{O}$ distele la teta de tal manera que le lastimaste y no pudo más mamar? ¿O durmiendo te echaste sobre él y murió?

Y cuando estabas preñada ¿Apretaste el vientre para mover y matar a tu hijo? ¿Quizá no se bautizó? ¿Llevaste alguna carga o moviste algo, por donde lo veniste a mover? ¿Bebiste algunos bebedizos para te hacer estéril y sin fruto y para no poder más engendrar? ${ }^{34}$

De esta forma la mujer no tenfa derecho sobre su cuerpo, el cual pertenecia al marido -según la deuda marital-, ni sobre su "semen" ni sobre el producto del embarazo en cualquiera de sus fases de gestación. Del mismo modo, el varón tampoco tenfa derecho sobre su cuerpo, al servicio de la mujer, ni sobre su semen y menos aún sobre el producto; toda vez que se daba la cópula, éste era intocable para la iglesia.

Finalmente, según el discurso eclesiástico, era ella misma -la iglesiaquien daba a las mujeres en matrimonio, y no era sino Dios quien mandaba los hijos que tendria cada familia.

Si bien las prohibiciones a los anticonceptivos (al margen de que se desconozca la efectividad y frecuencia con que se usaban) y su encasilla-

${ }^{82}$ Flandrin, "Contraception...", op. cit., p. 13.

${ }^{83}$ Alberro Solange, "Mujeres ante el tribunal del Santo Oficio'de la Inquisición en Nueva España", taller de historia de la mujer/PiEM, El Colegio de México, México, 1984, p. 13.

84 Molina, op. cit., p. 31. 
miento en brujería e infanticidio le otorgan a la regulación eclesiástica un carácter marcadamente pronatalista, hay que apuntar que más importante es el hecho de que la iglesia reprueba cualquier relación sexual que no conduzca al embarazo; lo cual indica que no solamente hay una fuerte protección para los nacimientos desde el momento mismo del embarazo, sino que - lo que es más importante- los márgenes de la sexualidad en el matrimonio, la única sexualidad permitida, crean una fuerte compulsión a procrear.

Son los hijos la demostración de que Dios bendice el matrimonio, y además, el testimonio viviente de las costumbres sexuales sanas de los padres. ¿O es que existía una mejor prueba de que no se consumaban prácticas perversas e infecundas, pecados contra natura y costumbres perniciosas, que la prole misma? Así, los hijos son a un tiempo el testimonio y el fin del buen matrimonio. La prueba de que las relaciones sexuales se han llevado a cabo sin ofender a Dios.

La norma eclesiástica y sus implicaciones demográficas

El control eclesiástico sobre las características que debían reunir los novios, la edad a la cual debían contraer primeras nupcias, las limitaciones para tomar pareja entre parientes cercanos, el rumbo que debían tomar las relaciones conyugales y los propósitos que debía seguir el matrimonio implicaba un modelo de recuperación demográfica de la población. Es decir, se favorecía que las cohortes entraran cuanto antes posible a la vida reproductiva, sobre todo en el caso de las mujeres, de quienes se pensaba que estaban listas para casarse cuando estaban listas para procrear. Para la iglesia, en el periodo que nos atañe, el inicio de exposición al riesgo de concebir debía coincidir con la edad a la primera unión; esto implicaba que la puesta en reproducción de una cohorte de mujeres tiende a ser la mínima biológica necesaria, y que el tiempo bajo el cual las mujeres bien casadas están expuestas al riesgo de concebir tiende también a ser el máximo posible.

La iglesia, al convertir la decisión de casarse en un problema de conciencia cristiana, sobre todo en búsqueda de la salvación individual, y al establecer severas prohibiciones de parentesco en las nupcias intra étnicas, propuso, sin especificarlo, un modelo de enlace exogámico, un patrón de nupcias integrador.

Un estricto seguimiento de las normas es impensable si no se cuenta con la mezcla racial, sobre todo cuando se trata (como indudablemente es el caso de las poblaciones novohispanas) de grandes diferencias en los contingentes de los grupos étnicos. La moral matrimonial conduce a los 
matrimonios mixtos y, por ende, al mestizaje. Ahora bien, hemos visto que en el caso de los indios había una mucho mayor flexibilidad a la hora de aplicar las prohibiciones religiosas sobre parentesco; lo cual sucedía en menor medida con las castas y simplemente no sucedía, en el papel, con los españoles. Es decir, por parte de la iglesia no había en este aspecto un perfil único sobre los campos étnicos donde varones y mujeres debían escoger pareja, si bien la mera existencia de la prohibición del incesto -aún en los casos en los que los campos vedados se restringen- conlleva necesariamente a favorecer los matrimonios mixtos y el mestizaje, aunque las aportaciones de cada grupo racial se den, por las diferencias señaladas en la aplicación, en diferentes tiempos y a diferentes ritmos.

La modelación religiosa de las relaciones conyugales, según hemos considerado, y la manera en que éstas deben adecuarse cuando la esposa está embarazada, conducen también a favorecer la procreación. También hemos visto que los pocos espacios, dentro de la ética matrimonial, donde es contemplada una cierta igualdad conyugal de derechos y obligaciones se dan alrededor del débito conyugal, primero, y de la concepción y la crianza de los hijos, después. Las severas condenas impuestas a las prácticas sexuales llamadas deshonestas y pecaminosas, así como la poco clara asociación que se hacía entre tales ayuntamientos y la esterilidad, tienden a producir en las jóvenes parejas una fuerte compulsión a procrear hijos. Por consiguiente, embarazarse y dar a luz tantas veces como sea posible es una forma de probar, a la luz pública, que no existen vicios sexuales privados, toda vez que la forma natural de ayuntarse es concebida como la única vía fértil y, con ello, la única permitida.

Fincar los fines del matrimonio en la generación de los hijos, así como prohibir, bajo las más severas penas, los métodos -efectivos o no- anticonceptivos y abortivos, no es sino proponer un régimen de fecundidad natural, al cual asiste toda la concepción eclesiástica sobre las relaciones conyugales matrimoniales.

Existen, por otra parte, silencios en el discurso eclesiástico cuyas implicaciones habría que intentar subrayar. Una de ellas se refiere a las segundas y ulteriores nupcias, de las cuales se ha dicho que eran vistas con franca hostilidad por la iglesia. Esto sobre el argumento según el cual volverse a casar era -finalmente- mostrar excesiva debilidad ante la concupiscencia. Sin embargo no existe ningún tipo de penas para los que se volvían a casar. Lo cierto es que estaba permitido y que el silencio de la regulación era tomado por los segundos esposos como una aprobación discreta. El hecho de que no fueran exactamente iguales las ceremonias para primeras que para segundas nupcias, y el de que los viudos pretendientes debían seguir mayores trámites para obtener la venia religiosa, no significa, en modo alguno, que se buscara inhibir las segundas nupcias.

A fin de cuentas el trámite de pretendientes viudos era distinto por- 
que siempre existía la posibilidad de que uno de los solicitantes estuviera ya casado, ante lo cual había que cerciorarse de que no se iba a cometer el delito de bigamia con la cooperación eclesiástica. Sin duda, la conceptuación global del matrimonio en cuanto a sus fines y medios se aplicaba lo mismo para solteros mancebos y doncellas que para solteros viudos y viudas. Además no se hacía ningún tipo de distinción entre los matrimonios de mancebo con viuda, o viudo con doncella, y los demás; la iglesia buscó que todo el que no hubiera hecho votos de castidad estuviera casado y por tal motivo se puede decir que también alentaba las segundas nupcias.

Este proyecto de recuperación demográfica según el cual las cohortes entran a su fase reproductiva lo antes posible y están el más amplio tiempo expuestas al riesgo de concebir, teniendo estrictamente prohibido realizar cualquier tipo de acto contra la concepción desde el momento mismo de la cópula, así como la conceptuación del débito conyugal -según el cual la cohabitación es un derecho y obligación que asiste a cualquiera de los esposos-, es muy parecido a los que se han observado como siguientes a una crisis demográfica.

¿Querría decir esto que la iglesia sólo era cabalmente obedecida en los años inmediatos posteriores a las crisis demográficas, en lo que a ética matrimonial se refiere? Esa pregunta tendría que investigarse, pues no podemos partir de que los patrones de nupcialidad novohispanos se deban exclusivamente a la regulación de la iglesia, toda vez que - hasta donde se ha investigado- no existe un patrón para Nueva España, sino que hay grandes diferencias según regiones, etnias y tiempos. Además, la simple comparación entre los valores ideales de la edad a la primera unión, la proporción de segundas y ulteriores nupcias, la proporción de matrimonios mixtos, las tasas de ilegitimidad y el número de hijos por familia y los valores que tales variables asumen en determinada parroquia no constituyen una base suficiente para establecer una relación de carácter causal entre la ética matrimonial y el patrón de nupcialidad, y menos aún se puede afirmar que la tal región es más cristiana que tal otra porque sus parroquianas se casan, en promedio, tantos años antes.

Para conocer los alcances de una propuesta, sea causal o no, es menester evaluar los medios e instrumentos con que cuenta la institución en turno, así como la fuerza, la credibilidad y la voluntad de que dispone para pretender hacerse obedecer. Además, ninguna propuesta sobre comportamientos demográficos es recibida sumisamente por los protagonistas de tales fenómenos. Las instituciones -y la iglesia novohispana no es la excepción- no actúan sobre conciencias en blanco. Por ello, pese a provenir de la institución con mayor prestigio de la sociedad colonial, la doctrina religiosa no fue acogida pasivamente por las poblaciones a ella sujetas. A este respecto, Flandrin señala que la doctrina eclesiástica nunca se 
ha estructurado sobre conciencias vírgenes, sino que cada medio social busca el cómo adaptarla a sus necesidades, a sus creencias tradicionales, a sus hábitos de trabajo y de vida, admitiéndola, transformándola o rechazándola.

Si bien sólo un estudio de esa naturaleza nos podría revelar el carácter de la relación que vincula a las prescripciones de la ley religiosa con los fenómenos demográficos de nupcialidad y fecundidad, es indudable que, siendo la sociedad neohispana una sociedad eminentemente cristiana, los estudiosos de la demografía histórica (¿y los de la contemporánea?) no pueden pasar por alto la influencia que la religión ejerce sobre las pautas reproductivas de las poblaciones en estudio, a la hora de pensar en la interpretación y explicación de los comportamientos demográficos.

\section{Bibliografía}

Alberro, Solange, "Introducción a la historia de las mentalidades", 1979, DIH/INAH, México, D.F.

1984, "Mujeres ante el Tribunal del Santo Oficio de la Inquisición en la Nueva España", trabajo presentado en el PIEM/El Colegio de México, México, D.F. Alberro, et al., El afán de normar y el placer de pecar, 1986, Planeta, México, D.F. Annales E.S.C., Histoire et séxualité (número especial), 1974, julio-agosto.

Arrom, Silvia M., "Women and family in Mexico City", 1977, Stanford University (Ph.D. dissertation), Stanford.

, 1978, "Marriage patterns in Mexico City, 1811", en Journal of Family History núm. 3.

Burguiere, André, "Les estructures familiales. Pour una typologie des formes d'organization domestique", 1986, en Annales ES.C., mayo-junio, núm. 3.

Concilios Provinciales primero y segundo, celebrados en la muy Noble y muy Leal Ciudad de México, 1891, Imprenta del Agua, 2 vols., edición facsimilar de la de José de Hogal, 1769 (publicados por el arzobispo Lorenzana), México, D.F.

III Concilio Provincial Mexicano, 1859, Publicado por Mariano Galván Rivera, Eugenio Meillafort y Cía. ed. México.

Flandrin, Jean-Louis, "Contraception, mariage et relations amoreuses dans l'Occident chrétien", 1969, en Annales E.S.C., mayo-junio, núm. 3. , 1972, "Mariage tardif et vie sexuelle" en Annales E.S.C., nov.-dic., núm. 6. 1979, Los orígenes de la familia moderna, Grijalbo, Barcelona.

Giraud, François, "Mujeres y familia en Nueva España", 1984, trabajo presentado en el PIEM/El Colegio de México, México, D.F. ,1986, "Le viol au Nouvelle Espagne", en Annales E.S.C., mayo-junio.

Gonzalbo, Pilar, "Tradición y ruptura en la educación femenina del siglo xvl”, 1984, trabajo presentado en el PIEM/El Colegio de México, México, D.F.

Hajnal, J., "European marriage patterns in perspective", 1965, en Population in History.

Machuca Diez, A., Los sacrosantos concilios de Trento y Vaticano, en latín y castellano, 1903, Imprenta de R. Bouret, Madrid.

Molina, Alonso de, Confesionario Mayor en lengua mexicana, 1975 (1569) IIB/UNAM, México, D.F.

Noonan, John T., Contraception. A History of Its Treatment by Catholic Theologians and Canonists, 1965, Harvard University Press, Cambridge. 
Ortega, S. (comp.), Familia y sexualidad en Nueva España, 1980, FCE, México, D.F. Ortega, D. (ed.), De la santidad a la perversión, 1985, Grijalbo, México, D.F. Phelan, John L., The Milennial Kingdom of the Franciscans in the New World, 1956, University of California/Publications in History, vol. 52, Berkeley-Los Angeles. Rabell R., Cecilia A., El patrón de nupcialidad de una parroquia rural novohispana. San Luis de la Paz, 1978, Conacyt, México, D.F.

,1980, "La población novohispana a la luz de los registros parroquiales", tesis de maestria CEDDu/El Colegio de México.

Ripodas Ardanaz, D., El matrimonio en Indias. Realidad social y regulación jurídica, 1977, FEcC, Buenos Aires.

Viqueira, Juan P., "Matrimonio y sexualidad en los confesionarios en lenguas indigenas", 1984, en Cuicuilco, núm. 12.

Weckmann, Luis, La herencia medieval de México, 1982, El Colegio de México, México, D.F. 
